\title{
Does HCV Screening of Blood Donors Affect Transmission of Hepatitis G Virus in Dialysed Patients?
}

\author{
Gerard $\mathrm{Ch}^{[1]}$, Vaira $\mathrm{D}^{[1]}$, Delwaide $\mathrm{J}^{[2]}$, Lamproye $\mathrm{A}^{[2]}$, Maggipinto $\mathrm{G}^{[1]}$, Sondag $\mathrm{D}^{[1]}$, Rorive $\mathrm{G}^{[3]}$, \\ Belaïche $\mathrm{J}^{[2]}$, Rentier $\mathrm{B}^{[4]}$
}

\author{
${ }^{[1]}$ Service d'Immuno-Hematologie,Centre Hospitalier Universitaire de Liege, Sart Tilman, Liege, \\ Belgique \\ ${ }^{[2]}$ Service de Gastro-Enterologie,Centre Hospitalier Universitaire de Liege, Sart Tilman, Liege, \\ Belgique \\ ${ }^{[3]}$ Service de Dialyse renale, Centre Hospitalier Universitaire de Liege, Sart Tilman, Liege, Belgique \\ ${ }^{[4]}$ Service de Virologie fondamentale,Centre Hospitalier Universitaire de Liege, Sart Tilman, Liege, \\ Belgique
}

GBVC, or hepatitis G virus (HGV), is a recently identified virus, transmissible by blood, which has been reported to be associated with HCV in around $20 \%$ of cases [1,2]. Since screening for HCV antibodies in blood donors became mandatory in Belgium in July 1990, it appeared worthwhile to investigate a possible effect of $\mathrm{HCV}$ donor screening on the transmission of HGV in patients undergoing hemodialysis. The patient cohort studied included 82 dialyzed patients $(51 \mathrm{men}, 31$ women) aged 18-81 on dialysis for periods between 2 months and 28 years. In addition to their transfusion status, we also analysed known risk factors such as dialysis and kidney transplantation carried out prior to and after July 1990 for parenteral transmission of HCV and HGV The HBV, HCV, and HGV status of patients was determined by the detection of HBsAg (Auszyme Monoclonal and HBsAg Neutralization Assay, Abbott), anti-HCV (HCV EIA 3.0 and HCV Supplemental Assay, Abbott), and HGV RNA by RT-PCR using primers (i.e. G8-G11) derived from the NS3 genomic region of $\mathrm{HGV}$ [3].

The overall prevalence of viral markers in our patient cohort was $11 \%(9 / 82)$ for anti-HCV, 15,9\% (13/82) for HGV RNA and 3.7\% (3/82) for HBsAg. HGV RNA was more often found alone (9/13), while in the coinfected it was associated with either HBsAg (2 patients) or anti-HCV (2 patients). HGV RNA was never found associated with concurrent $\mathrm{HBV}$ and $\mathrm{HCV}$ infection. Interestingly, liver enzymes (ALT) in 10 of 13 HGV RNA-positive patients were normal. Of the 3 patients with elevated ALT levels, 1 was coinfected with HBV (HBeAg-positive), the second with HCV, and the third had fatty liver infiltration associated with insulin-dependent diabetes.

As far as the prevalence of HGV infection is concerned, there was no statistically significant difference between patients who were dialyzed, transfused or transplanted prior to or after July 1990. It is worth noting that the $13.3 \%$ (4/30) prevalence of HGV RNA among patients transfused after 1990 was lower than the $20 \%$ prevalence (8/40) among those transfused prior to 1990 . However, this difference did not reach statistical significance. As expected, implementation of anti-HCV screening in 1990 was strongly associated with a dramatic reduction in transmission of HCV in dialyzed and transfused patients. In fact, the seroprevalence of HCV fell from 20\% (8/40) prior to 1990 to $3.3 \%(1 / 30)$ after 1990 (p<0.05). In all but 1 polytransfused patient (see patient (a) in table 1), HCV infection could be traced to transfusions received prior to 1990 .

We conclude that HCV screening of blood donors proved to be efficient in preventing blood transfusion-transmitted $\mathrm{HCV}$ in our cohort of dialyzed patients without a concomitant significant effect on the transmission of $\mathrm{HGV}$.

Table 1. Prevalence of HGV and HCV in patients who began to be dialyzed, transfused or transplanted prior to, or after July 1990

\begin{tabular}{|c|c|c|c|c|c|c|c|}
\hline Medical event & Before/after 1990 & $\begin{array}{l}\text { HGV } \\
\text { positive }\end{array}$ & negative & $\chi ; p$ & $\begin{array}{l}\text { HCV } \\
\text { positive }\end{array}$ & negative & $\chi ; p$ \\
\hline \multirow[t]{2}{*}{ First dialysis } & before & 6 & 22 & NS & 7 & 21 & $<0.005$ \\
\hline & after & 7 & 47 & & $2^{\mathrm{a}, \mathrm{b}}$ & 52 & \\
\hline Transfusion & $\begin{array}{l}\text { before } \\
\text { after }\end{array}$ & $\begin{array}{l}8 \\
4\end{array}$ & $\begin{array}{l}32 \\
26\end{array}$ & NS & $\begin{array}{l}\mathbf{8} \\
\mathbf{1}^{\mathbf{a}}\end{array}$ & $\begin{array}{l}32 \\
29\end{array}$ & $<0.05$ \\
\hline Transplantation & before & 4 & 8 & NS & 5 & 7 & NS \\
\hline
\end{tabular}


Published in : Vox sanguinis (1998), vol. 75, iss. 1, p. 77

Status : Postprint (Author's version)
after
2
5
$\mathbf{1 b} \quad \mathbf{6}$

a Between 1995 and 1997, this polytransfused patient received 75 packed RBC, 150 plasma and 73 platelet units.

Patient was transfused before July 1990.

\section{References}

[1] Barbara J: Does GB virus C (hepatitis G virus) threaten the safety of our blood supply? Transfus Med 1997;7:75-76.

[2] Alter MJ, Gallagher M, Morris TT, Moyer LA, Meeks EL, Krawczynski K, Kim JP, Margolis

HS: Acute non-A-E hepatitis in the United States and the role of hepatitis G virus infection. N Engl J Med 1997;336:741-746.

[3] Linnen J, Wages J Jr, Zhang-Keck ZY, et al: Molecular cloning and disease association of hepatitis G virus: A transfusion-transmissible agent. Science 1996;271:505-508. 